\title{
Lithium-Ion Batteries as Ignition Sources in Waste Treatment Processes-A Semi-Quantitate Risk Analysis and Assessment of Battery-Caused Waste Fires
}

\author{
Thomas Nigl ${ }^{1, *(\mathbb{D}}$, Mirjam Baldauf ${ }^{1}$, Michael Hohenberger ${ }^{2}$ and Roland Pomberger ${ }^{1}$ \\ 1 Chair of Waste Processing Technology and Waste Management, Montanuniversitaet Leoben, 8700 Leoben, \\ Styria, Austria; mirjam.baldauf@unileoben.ac.at (M.B.); roland.pomberger@unileoben.ac.at (R.P.) \\ 2 Chair of Thermal Processing Technology, Montanuniversitaet Leoben, 8700 Leoben, Styria, Austria; \\ michael.hohenberger@unileoben.ac.at \\ * Correspondence: thomas.nig1@unileoben.ac.at
}

check for updates

Citation: Nigl, T.; Baldauf, M.; Hohenberger, M.; Pomberger, R. Lithium-Ion Batteries as Ignition Sources in Waste Treatment Processes-A Semi-Quantitate Risk Analysis and Assessment of Battery-Caused Waste Fires. Processes 2021, 9, 49. https://doi.org/10.3390/pr9010049

Received: 30 November 2020 Accepted: 24 December 2020 Published: 29 December 2020

Publisher's Note: MDPI stays neutral with regard to jurisdictional claims in published maps and institutional affiliations.

Copyright: () 2020 by the authors. Licensee MDPI, Basel, Switzerland. This article is an open access article distributed under the terms and conditions of the Creative Commons Attribution (CC BY) license (https: / / creativecommons.org / licenses/by/4.0/).

\begin{abstract}
Increasing occurrences of waste fires that are caused by improperly discarded lithiumbased portable batteries threaten the whole waste management sector in numerous countries. Studies showed that high quantities of these batteries have been found in several municipal solid waste streams in recent years in Austria. This article reveals the main influence factors on the risk of lithium-based batteries in their end-of-life and it focuses on the quantification of damages to portable batteries during waste treatment processes. Hazards are identified and analysed and potential risks in waste management systems are comprehensively assessed. In two scenarios, the results showed that the potential risks are too high to maintain a sustainable form of waste management. According to the assessment, a small fire in a collection vehicle is located in the risk graph's yellow region (as low as reasonably practicable, ALARP), while a fully developed fire in a treatment plant has to be classified as an unacceptable risk (red region of risk graph). Finally, basic recommendations for action were made.
\end{abstract}

Keywords: risk modelling; portable batteries; lithium batteries; fire hazards; waste management

\section{Introduction \\ 1.1. Background}

In Austria and other European countries, like Germany, France or Sweden, the occurrences of waste fires has increased enormously in the last years [1-3]. The subsequent monetary and infrastructural losses have reached a new peak and they are threatening the whole waste industry sector [4].

Recent research showed that high amounts of portable batteries are improperly discarded in different municipal solid waste streams, such as residual household waste, lightweight packaging waste, or metal packaging waste [5]. While there is a plethora of different electrochemical systems, the average distribution is shifting more and more towards metal lithium and lithium-ion. That shift is accompanied by increased fire hazards and other safety challenges all along the value chain in the batteries' end-of-life.

\subsection{Battery Content and Battery Composition}

In Austria, the collection rate for portable batteries sank from 55\% in 2015 to $45 \%$ in 2017 and it has stayed on that low level ever since [6,7]. A lot of the batteries that are not collected properly are falsely disposed in different municipal solid waste fractions [5]. Material flow analysis revealed that: (1) about 718 tonnes end up in residual household waste, (2) about 41 tonnes in lightweight packaging waste, and (3) about 17 tonnes in metal packaging waste.

For material flow analysis (MFA), [4] investigated the battery content and battery composition of the following waste streams: (1) residual household waste, (2) lightweight packaging 
waste, and (3) metal packaging waste. In addition to the quantitative weight-related values for MFA, particle-related data were published in [4] and they are given in Table 1.

Table 1. Particle-based data for portable and lithium batteries in various municipal waste streams (data from [4]).

\begin{tabular}{|c|c|c|c|c|c|}
\hline Waste Streams & $\begin{array}{c}\text { Waste Generation } \\
2016[t]\end{array}$ & $\begin{array}{c}\text { Portable Batteries } \\
\text { [items/t] }\end{array}$ & $\begin{array}{c}\text { Portable Batteries } \\
2016 \text { [items] }\end{array}$ & $\begin{array}{c}\text { Lithium Batteries } \\
\text { [items/t] }\end{array}$ & $\begin{array}{c}\text { Lithium Batteries } \\
\text { [items] }\end{array}$ \\
\hline Residual waste & $1,436,700$ & 20 & $28,734,000$ & 1 & $1,436,700$ \\
\hline Lightweight packaging waste & 156,700 & 14 & $2,193,800$ & 0.8 & 125,360 \\
\hline Metal packaging waste & 30,000 & 33 & 990,000 & 1 & 30,000 \\
\hline
\end{tabular}

\subsection{Hazards of Lithium-Ion Batteries in End-of-Life}

Lithium-ion batteries may undergo thermal runaway and uncontrolled heat release when they are electrically (e.g., over-charged, deep discharged), mechanically (e.g., penetration, crushing, vibration), or thermally (e.g., externally heated) damaged due to the increased energy density $[8,9]$. Hence, they may act as ignition sources leading to fire incidents during waste management processes, especially in the case of thermal or mechanical abuse [4].

According to [10], even severe crushing of cells that are below approximately $50 \%$ state-of-charge (SOC) will not lead to a severe reaction. Golubkov et al. [11] further investigated the influence of SOC on the thermal runaway behaviour of the two lithiumion battery subtypes and found out that, after thermal abuse, lithium-ion cells with $\mathrm{Li}_{\mathrm{x}}\left(\mathrm{Ni}_{0.80} \mathrm{Co}_{0.15} \mathrm{Al}_{0.05}\right) \mathrm{O}_{2}$ cathodes (NCA) displayed an unmistakable thermal runaway when SOC was $\geq 25 \%$. In the same way, lithium-ion cells with $\mathrm{Li}_{x} \mathrm{FePO}_{4}$ cathode (LFP) showed mild exothermic reactions when the SOC was $\geq 25 \%$ and pronounced thermal runaway when SOC was $\geq 50 \%$. Liu et al. [12] revealed that lithium-ion batteries with a lithium nickel manganese cobalt oxide cathode (NMC) show thermal runaway behaviour when the SOC is $\geq 25 \%$.

Furthermore, due to significant differences in safety performance, waste batteries impose a higher safety hazard than new batteries, the majority of which are thoroughly tested before market input [8].

\subsection{State-of-Charge}

Based on that, ref. $[13,14]$ shed light on the distribution of SOC in end-of-life portable lithium-based batteries. ref. [13] found out that $11.4 \%$ of tested lithium-based batteries showed an SOC that was higher than $25 \%$ in the end-of-life. However, it is unknown how many batteries or cells were tested in the study. According to the results of [14], where 980 batteries were analysed, approximately $24 \%$ of the tested batteries showed an SOC higher than $25 \%$ (Table 2 ).

Table 2. Distribution of state of charge (SOC) of end-of-life lithium-ion batteries.

\begin{tabular}{cccc}
\hline $\begin{array}{c}\text { Share of Batteries/Cells with } \\
\text { SOC } \geq \mathbf{2 5 \%}\end{array}$ & $\begin{array}{c}\text { Share of Batteries/Cells with } \\
\text { SOC } \geq \mathbf{5 0 \%}\end{array}$ & $\begin{array}{c}\text { Number of Batteries/Cells } \\
\text { Analysed }\end{array}$ & Reference \\
\hline 11.4 & 4.9 & NA & {$[13]$} \\
23.6 & 12.0 & 980 & {$[14]$} \\
\hline
\end{tabular}

\subsection{Risk Analysis and Risk Assessment}

Risk may be defined as consequences and its associated uncertainty or the combination of frequency or probability of occurrence and the severity or extent of damage [15]. When considering waste fires as the generalised hazard, the probability of an occurring fire incident is the first term, the expected financial losses the second term of the equation (Equation (1)):

$$
R=\text { probability of fire incident } \times \text { (expected) loss in case of the incident }
$$


If not, a single event is considered, but the sum of risks (e.g., for a single waste management company or the whole waste industry), Equation (2) is applied:

$$
R=\sum_{\substack{\text { for all } \\ \text { incidents }}} \text { probability of fire incident } \times(\text { expected }) \text { loss in case of the incident }
$$

\subsection{Study Objectives}

The article presents a new method for risk evaluation and the assessment of portable batteries and. especially, lithium-based batteries in waste management systems strongly focused on the first term of Equations (1) and (2).

The following research questions are answered:

1. What are the primary influence factors regarding the risk of portable batteries in waste management systems?

2. What are the qualitative hazards of portable batteries in different waste management systems?

3. What are the quantitative risks of portable batteries in different waste management systems?

\section{Materials and Methods}

Risk analysis is the systematic use of information in order to identify hazards and estimate risks to individuals, property, and the environment. There are three main steps in the analysis of risks: (1) hazard identification, (2) frequency analysis, and (3) consequences analysis [16].

Because the exact number of fires triggered by lithium-ion batteries is not even approximately known [1], no direct probability of occurrence can be achieved [13]. Therefore, an alternative approach is taken in this study to quantify the risks of lithium-ion batteries in waste management systems.

The probability of a battery-caused fire incident $\left(F I_{B C}\right)$ can be expressed as the product of two terms: (1) the probability of the presence of a hazardous battery and (2) the probability of critical damage done to the present battery (Equation (3)):

$$
F I_{B C}=P(\text { presence of a hazardous battery }) \times P(\text { critical damage to the present battery })
$$

Figure 1 displays the overall approach and the boundaries of this study. After the basic step of literature research, two different workflows were followed. The first was covered by two previous publications and it is about the presence of a hazardous battery; the second, is about the critical damage done to a present battery (which, consequently, leads to a battery-caused fire) and it is covered by this study. Afterwards, the results are combined in the overall risk modelling and assessment.

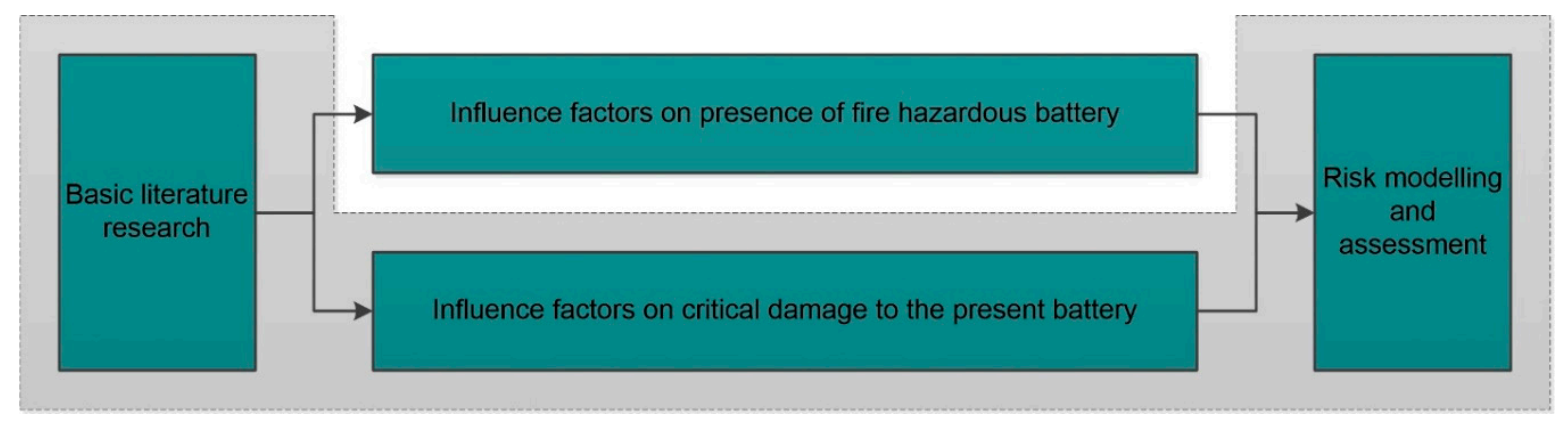

Figure 1. Overall approach and boundaries of this study (grey box).

More specifically, the first part of Equation (3) depends on the following influence factors (upper part of Table 3): (1) battery content in the respective waste stream [items/tonne], 
(2) percentage of lithium batteries within these batteries (both [5]), and (3) the percentage of lithium batteries that contain a critical state of charge (SOC) [13]. The second part of the equation depends on the (1) number and intensity of potential damaging incidents, (2) the size and shape of the respective batteries, and (3) the energy content of the batteries and ambient conditions (lower part of Table 3).

Table 3. Overview of the relevant influence factors on the presence of a fire-hazardous battery (1.1-1.3) and on critical damage to the present battery (2.1-2.3).

\begin{tabular}{ccc}
\hline Number & Influence Factor & Reference \\
\hline$(1.1)$ & Battery content in waste stream & {$[5]$} \\
$(1.2)$ & Battery composition (share of Li-based batteries) & {$[5]$} \\
$(1.3)$ & Share of Li-based batteries containing critical state-of-charge & {$[13,14]$} \\
\hline$(2.1)$ & Amount and intensity of potential damaging incidents & this study \\
$(2.2)$ & Size and shape of respective portable batteries & this study \\
$(2.3)$ & Energy content of the respective portable batteries and the surrounding conditions & this study \\
\hline
\end{tabular}

The parameters (1) the degree of damage, (2) size, and the shape (construction type) of the portable batteries were investigated for this study. Portable batteries that were collected during waste sorting and the characterisation campaign of the input fractions residual waste, lightweight packaging waste, metal packaging waste (compared to previous publication of [5]), and commercial waste and specific output waste fractions (of treatment plants for residual waste and lightweight packaging).

\subsection{Degree of Damage}

In Table 4, the description of the defined damage classes (DC) and respective degree of damage is given. DC 1 to 3 are considered as minorly damaged and DC 4 to 7 as majorly damaged. The classification was made visually during the manual documentation of the portable batteries in the laboratory. Sample pictures of the damage classes of portable batteries are given in Supplementary Materials.

Table 4. Overview of damage classes and description of the degree of damage.

\begin{tabular}{cc}
\hline Damage Class & Degree of Damage \\
\hline DC 1 & Undamaged or slightly scratched \\
DC 2 & Superficially damaged (e.g., label torn off), slightly deformed $(<10$ vol.- $\%)$ \\
DC 3 & Slightly deformed $(<50$ vol.- $\%)$, outer shell undamaged \\
DC 4 & Severely deformed $(>50$ vol.- $\%)$, outer shell undamaged \\
DC 5 & Deformed, outer shell damaged \\
DC 6 & Crushed, destroyed \\
\hline DC 7 & Heavily bloated or post-thermal runaway \\
\hline
\end{tabular}

Thereafter, the distribution of the degree of damage in the investigated waste fractions was used in order to model the potential damages, the portable batteries must endure between both (1) the intention to dispose of and the arrival at the waste treatment site and (2) the arrival at the treatment site and after running through the treatment process. Because of financial and time restraints, this was done for the fractions of residual household waste and lightweight packaging waste only.

As a background reference for the degree of damage that is occurring already during the use phase, the separated collection of portable batteries was also sampled and investigated accordingly. 


\subsection{Size and Shape of Batteries}

The size was measured as the maximal edge length $(\mathrm{mm})$ of the portable batteries, and the shape (the construction type, e.g., round cell, button cell, prismatic cell, and pouch cell) of the portable batteries was documented. These parameters are considered to have an influence on the likelihood of critical damage (causing a waste fire). Hence, the distribution patterns of these parameters were investigated and documented.

\subsection{Energy Content and Surrounding Conditions}

When considering the various possible scenarios, the exact thermodynamic modelling of the potential ignition of waste that is caused by a portable battery must be based on many parameters. Thus, many underlying assumptions would be necessary.

For example, the ignition temperature of different plastic types ranges from $350{ }^{\circ} \mathrm{C}$ (polyethylene) to $580^{\circ} \mathrm{C}$ (polytetrafluoroethylene) [17]. Furthermore, [18] presented significantly lower values for the initial combustion temperature for plastics $\left(254-354{ }^{\circ} \mathrm{C}\right)$ and paper materials $\left(240-260^{\circ} \mathrm{C}\right)$. Golubkov et al. [11] showed that these temperatures are easily met when lithium-ion batteries (of type 18650) with an SOC $>25 \%$ (for NCA) or SOC $>50 \%$ (for LFP) undergo thermal runaway. However, it is known that a lower heating rate provides a lower ignition temperature, and vice versa [19]. A significant discrepancy in that regard can be seen, as [16] used a constant heating rate of $20 \mathrm{~K} / \mathrm{min}$. for defining the ignition temperature. Jhu [20] showed, under adiabatic conditions in a closed test can, that the peak temperature of the thermal runaway reaction of a fully charged 18650 lithium-ion cells is able reach its maximum temperature of $654.3^{\circ} \mathrm{C}$ in $0.49 \mathrm{~s}$ starting from $125.2^{\circ} \mathrm{C}$. In these experiments, four cells from different worldwide battery producers have been investigated.

Regarding the released energy from the runaway reaction, [21] measured 102 to $218 \mathrm{~kJ}$ per Ah, depending on cell chemistry and respective SOC for LFP and NMC cells. Consequently, a typical lithium-ion cell (type 18650, $2.6 \mathrm{Ah}$ ) would release thermal energy in the range of 265 and $567 \mathrm{~kJ}$. This energy can easily ignite various waste materials; still, the duration of the thermal runaway and ambient parameters will influence the ignition's success. The two main types of parameters can be distinguished between battery- and ambient-based.

The battery-based parameters depend on the type and SOC of the battery and they affect the following:

- the thermally convertible energy content of the battery,

- the reaction rate and temperature rise, and

- the heat release rate of the reaction.

Ambient-based parameters are:

- the ambient temperature,

- the distance between battery and other waste material,

- the moisture content of air and waste material,

- the composition of the surrounding waste material,

- the specific heat capacity and transfer coefficients, and

- the geometry of the loose or bulk material.

\subsection{Risk Modelling and Assessment}

Regarding risk modelling, the following assumptions were made:

- A stable content of portable batteries in the waste streams was assumed in the observed (2016) and projected period (2020) (cf. influence factor 1.1 of Table 3).

- Regarding the estimation of the risk potential in 2020, the content of lithium-based battery was assumed to raise (1) from one to two items/tonne for residual household waste and from (2) 0.8 to 1.5 items/tonne for lightweight packaging waste (cf. influence factor 1.2 of Table 3). 
- Because of methodological reasons, only lithium-ion batteries were tested for their SOC in the end-of-life [13]. It is assumed that the SOC of primary lithium batteries generally follows the same pattern. Hence, the distribution pattern of the investigated batteries was applied to all lithium-based batteries (cf. influence factor 1.3 of Table 3).

- The number and intensity of potential damaging incidents, which was derived from the degree of damage of the investigated portable batteries $(n=848)$, is assumed to be representative for the lithium-based batteries, which were not found in high numbers $(\mathrm{n}=66)$ (cf. influence factor 2.1 of Table 3).

- Portable batteries that are below a specific size are less likely damaged, due to (1) their relatively small maximal edge length and (2) their preferable mass-ratio of battery casing to active material. Furthermore, regarding the shape (construction type) of portable batteries, it is assumed that the stability of cells against mechanical abuse is as follows: button cells >> round cells/batteries, prismatic cells/batteries, battery packs $>>$ pouch cells/batteries. The assumed correction factors for size and shape were chosen accordingly (cf. influence factor 2.2 of Table 3).

- It is assumed that a battery undergoing thermal runaway or uncontrolled heat release is causing waste ignition and a sustained spreading of fire in $10 \%$ of the cases. In the other $90 \%$, it is assumed that either (1) the respective battery did not have enough energy to ignite flammable material, (2) there was not enough flammable material to be ignited, or (3) the flammable material could not sustain a chemical chain reaction and self-extinguished (cf. influence factor 2.3 of Table 3).

- For risk modelling, the generated amounts of waste (of residual waste and lightweight packaging waste) were taken for the year 2016, according to [22], and extrapolated accordingly from the data 2012-2018 for the year 2020 [23].

The probability of occurrence followed typical grading schemes for risk graphs/risk matrices (e.g., as low as reasonably practicable, ALARP) e.g., [13,24]:

The probability of occurrence:

- $\quad$ likely <1:100;

- rarely 1:100-1:1000;

- $\quad$ very rarely 1:1000-1:10,000;

- unlikely 1:10,000-1:100,000;

- very unlikely 1:100,000-1:1,000,000; and,

- $\quad$ extremely unlikely $>1: 1,000,000$.

Property damage/losses:

- negligible no noticeable consequences of fire;

- minor no appreciable fire damage;

- $\quad$ severe low property damage;

- major high property damage; and,

- catastrophic very high property damage/

\section{Results}

Table 5 shows the identification and risk assessment of the possible hazards and threats of portable batteries for different facility areas or processes along the value chain of a residual household waste system.

\subsection{Damage Degree}

Table 6 presents the distribution of investigated portable batteries' maximal edge length. The main findings are:

- It is relevant to mention that many of the investigated portable batteries have just two well-known form factors: AA and AAA. That is why the high frequencies of the maximal edge length intervals are 30.0-44.9 $\mathrm{mm}$ and $45.0-59.9 \mathrm{~mm}$.

- Small portable batteries (maximal edge length $<30 \mathrm{~mm}$ ) have a relatively low share of the DC 4 to 7. 
- $\quad$ Larger portable batteries (maximal edge length $>30 \mathrm{~mm}$ ) show a relatively high share of the DC 4 to 7.

Table 5. Qualitative risk assessment of possible hazards and threats of portable batteries (waste stream: residual household waste).

\begin{tabular}{|c|c|c|}
\hline Facility Area/Process & Possible Hazards and Threats & Risk Assessment \\
\hline Collection bins & Damage due to external short-circuit & low \\
\hline Loading activity & Damage due to external short-circuit & low \\
\hline Collection vehicle & Mechanical damage due to compaction & medium \\
\hline Unloading activity & Mechanical damage due to tip-off & low \\
\hline Waste bunker/input storage & $\begin{array}{l}\text { Damage due to external short-circuit } \\
\text { Damage due to external heating (self-heating of waste) }\end{array}$ & medium-high \\
\hline Waste transfer activity & Mechanical damage due to (wheel) loader or gripper & medium \\
\hline Treatment facility & $\begin{array}{l}\text { Mechanical damage due to pre-shredding process } \\
\text { Mechanical damage due to post-shredding process } \\
\text { Dangerous heat generation after damage } \\
\text { Carry-over through the processing facility }\end{array}$ & high-very high \\
\hline Output storage & $\begin{array}{l}\text { Damage due to external short-circuit } \\
\text { Damage due to external heating (self-heating of waste) } \\
\text { Dangerous heat generation after damage }\end{array}$ & low-medium \\
\hline
\end{tabular}

Table 6. Distribution of maximal edge length of the investigated portable batteries.

\begin{tabular}{ccccc}
\hline $\begin{array}{c}\text { Maximal Edge } \\
\text { Length [mm] }\end{array}$ & $\begin{array}{c}\text { Amount of Batteries } \\
\text { [items] }\end{array}$ & $\begin{array}{c}\text { Amount in damage } \\
\text { Classes 4-7 [items] }\end{array}$ & $\begin{array}{c}\text { Share of Damage } \\
\text { Classes 4-7 [\%] }\end{array}$ & $\begin{array}{c}\text { Assumed Correction } \\
\text { Factor }\end{array}$ \\
\hline-14.9 & 41 & 2 & $4.9 \%$ & 0.40 \\
$15.0-29.9$ & 54 & 4 & $3.4 \%$ & 0.75 \\
$30.0-44.9$ & 292 & 100 & $29.2 \%$ & 0.95 \\
$45.0-59.9$ & 430 & 127 & $26.7 \%$ & \\
$60.0-$ & 30 & 8 & $28.5 \%$ & \\
Total & 847 & 241 & & \\
\hline
\end{tabular}

In Figure 2, the distribution of the portable batteries' damage degree according to the waste stream in which they were found.

Only two per cent of the spent batteries show a relevant degree of damage, according to the background reference sample (separated portable battery collection, SBC) (DC 4 to 7). The vast majority of over $97 \%$ of the batteries are undamaged (DC 1). No portable battery was found, which was heavily bloated or in a post-thermal runaway state (DC 7).

The input fractions results show that, on the one hand, portable batteries can already be subject to varying degrees of mechanical damage during collection, e.g., due to the force that is applied in press containers of collection vehicles. That is particularly remarkable when compared to the separate collection of portable batteries, as batteries are or will be damaged only to a minor extent in this collection system.

On the other hand, there is a significant degree of damage to portable batteries in processing plants, for example, during the conditioning of the waste stream by a preshredder (e.g., in residual waste treatment) or a bag opener (e.g., in lightweight packaging waste sorting), but also during the manipulation of the waste stream (while using a wheel loader or gripper). Other impacts, such as (1) shock loads, which may occur due to different drop heights in treatment processes (e.g., by falling into an output box or from one conveyor belt to another), or (2) vibration of vibrating conveyors can also damage portable batteries.

Moreover, when comparing the residual household waste before (RHW (in)) and after (RHW (out)) treatment in a respective facility, it is noticeable that the percentage of 
the lower degrees of damage (DC 1 to 3 ) are reduced, while the percentage of the higher damage classes (DC 4 to 6 ) are increased (from approximately $6 \%$ to over $40 \%$ in total).

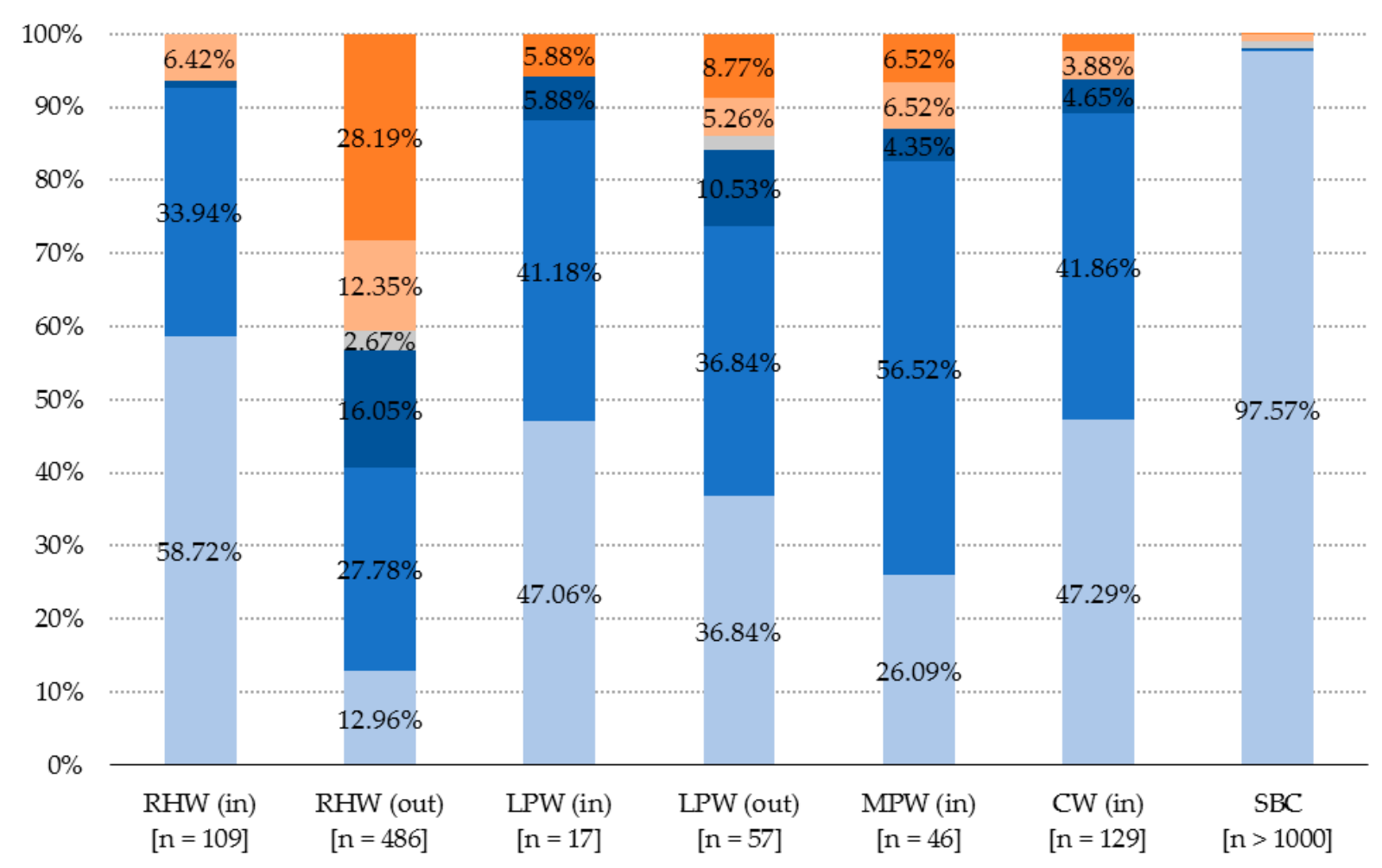

$\square \mathrm{DC} 1 \square \mathrm{DC} 2 \square \mathrm{DC} 3 \square \mathrm{DC} 4 \quad \mathrm{DC} 5 \square \mathrm{DC} 6$

Figure 2. Distribution of damage degree according to the waste stream in which the batteries were found (Legend: RHW = residual household waste, $\mathrm{LPW}=$ lightweight packaging waste, $\mathrm{MPW}=$ metal packaging waste, $\mathrm{CW}=\mathrm{commercial}$ waste, $\mathrm{SBC}=$ separate portable battery collection; values $<2 \%$ not displayed).

When comparing lightweight packaging waste before (LPW (in)) and after (LPW (out)) treatment (sorting plant), the effect is similar, but yet not that severe, which results in an increase of DC 4 to 6 from almost $6 \%$ to $14 \%$ in total. The share of DC 4 to 6 in commercial waste (CW (in)) is very similar to the input fractions of residual household waste and lightweight packaging waste, and it is notably much higher in metal packaging waste (MPW (in)).

\subsection{Shape Distribution Pattern}

Regarding the shape (construction type) of the portable batteries, the distribution pattern is shown in Table 7. The share of round cells/batteries is very high (about 85\%), due to the aforementioned high quantities of portable batteries with the format factors AA and AAA. It was observed that lithium-ion batteries are often prismatic or pouch-shaped.

Table 7. Shape/construction type of the analysed portable batteries.

\begin{tabular}{cccc}
\hline Battery/Cell Type & No. of Cells Analysed [items] & Share of Cells Analysed [\%] & Assumed Correction Factor \\
\hline Button cell & 93 & 11.0 & 0.20 \\
Round cell/battery & 717 & 84.6 & 0.75 \\
Prismatic cell/battery & 27 & 3.2 & 0.95 \\
Battery pack & 5 & 0.6 & \\
Pouch cell/battery & 5 & 0.1 & \\
unknown & 1 & 100 & \\
Total & 848 & 0.95 \\
\hline
\end{tabular}




\subsection{Risk Modelling}

Table 8 presents the results of the modelling of potential risk (in potential fire incidents per year), comparing residual household waste (RHW) and lightweight packaging waste (LPW). The values are based on fictitious waste systems with 100,000 tonnes per year of the respective fractions of residual household waste and lightweight packaging waste (2016). For 2020, the assumed growth was included, which was linearly extrapolated, which resulted in a two per cent increase for residual waste and a four percent increase for lightweight packaging waste.

Table 8. Risk modelling for portable and lithium-based batteries in residual household waste (RHW) and lightweight packaging waste (LPW).

\begin{tabular}{ccccc}
\hline Modelling of Risk Potential & RHW Projection 2016 & RHW Estimate 2020 & LPW Projection 2016 & LPW Estimate 2020 \\
\hline Waste generation [t] & 100,000 & 102,000 & 100,000 & 42 \\
\hline $\begin{array}{c}\text { in waste collection } \\
\text { [pot. fire incidents/year] }\end{array}$ & 57 & 116 & $1: 1904$ & 104,000 \\
\hline Probability of occurrence & $1: 1754$ & $1: 1758$ & 103 & 202 \\
\hline $\begin{array}{c}\text { in waste treatment } \\
\text { [pot. fire incidents/year] }\end{array}$ & 363 & 741 & $1: 777$ & $1: 743$ \\
\hline Probability of occurrence & $1: 275$ & $1: 275$ & & \\
\hline
\end{tabular}

The risk potential is shown in potential fire incidents per year. The waste collection scenarios are very similarly related to the potential risk of fire, while the waste treatment scenarios differ more. Remarkably enough, the risk almost doubles in all of the observed scenarios.

The probability of occurrence is presented in a particle-based form and it reveals the high risks of battery-caused fire incipiencies in terms of likelihood.

\subsection{Risk Assessment}

The modified risk graph presented Figure 3 visualises the assessment of the risk of portable lithium-based batteries. Two specific scenarios were chosen representing the observed areas of (1) collection and (2) treatment of waste from Table 8.

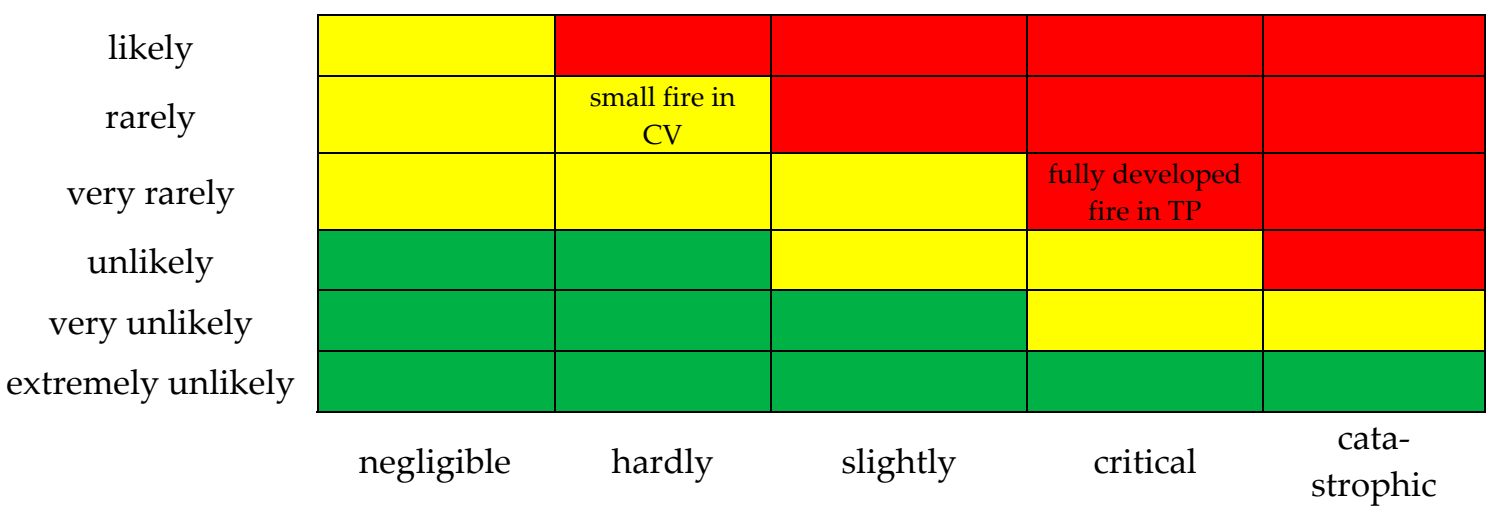

Figure 3. Modified risk graph for the two scenarios of Table 8: Waste collection (a small fire in a collection vehicle, CV) and waste treatment (a fully developed fire in a treatment plant, TP).

Keeping the grading of the probability of occurrence in mind, the various probabilities do not lead to different results in the risk graph, whether residual waste or lightweight packaging waste; however, they vary considerably in Table 8 . 


\section{Discussion}

A broad spectrum of potential hazards of batteries was considered within this study's investigations and it is presented in Table 5, being exemplary for residual household waste. However, from a holistic viewpoint, in complex systems, such as waste management systems, it is unlikely to cover all of the possible hazards that are posed by lithiumbased batteries.

As [25] stated, risk matrixes may be subject to biases or errors. A risk matrix can compare only a small fraction of more or less randomly selected hazards due to their low resolution. In general, that fact has to be kept in mind when risk graphs are created or the basis of decision-making.

The scenarios that were observed in detail reveal that the risks are either in the ALARP region (yellow area) or in the region of inacceptable risks (red area of the risk graph). For the latter, measures of risk reduction are inevitable.

Fires in waste collection vehicles have become a well-known phenomenon in recent years. The smoke of the fires is usually recognised by the vehicle drivers in an early stage. An unspoken best-practice measure of the respective vehicle driver is to choose a known asphalt or concrete surface that is big enough to unload the burning waste (e.g., parking area of a nearby supermarket) and call the local fire brigade. The waste is usually pulled apart during extinguishing in order to speed up the subsequent fire-fighting operations and to locate the origin of the fire.

The different results for RHW and LPW indicated that waste shredders are the main hot-spot for battery-caused waste fires. In contrast to shredders, bag openers in LPW sorting plants are not crushing the waste. That is also confirmed by a recently published study [26], revealing high numbers of battery-caused ignitions after pre- and post-shredders in treatment facilities for RHW and commercial waste.

The comparison of the data of potential fire incidents per year with values from literature allows for an overall evaluation of these results. In contrast to the statistical data of waste fire incidents [1,27], where relatively low numbers are determined battery-caused fires, the results of this study seem to be very high. The data of $[1,27]$ are characterised by high shares of unknown fire causes, which probably underestimates the relevance of battery-caused fires. In contrast to the high numbers of heat-related threshold exceedances in waste shredding machines found by [26], which are caused by batteries to a large extent, the results of this study seem appropriate. Autischer et al. [26] detected 0.1 to 1.5 threshold exceedances per eight-hour-work shift, depending on the respective measuring point in one of the two observed treatment plants. That means 260 to 1.580 threshold exceedances per year and treatment facility. In comparison to the results, it should be noted that (1) both treatment plants process significantly less than 100,000 tonnes per year and (2) temperature-related threshold exceedances are detected—not fire incidents.

\section{Conclusions}

In this article, the main influence factors on lithium-based portable batteries' risk were investigated in their end-of-life phase. The degree of damage that was happening to portable batteries was investigated and compared for different waste streams. After that, the hazards and potential risks were modelled and assessed, including the present and previous studies' findings.

The results included a detailed analysis of the damage degree, the distribution pattern of influencing characteristics of portable batteries, and profound risk analysis and assessment.

The assessment reveals that the risk of lithium-based portable batteries is significantly too high, which makes it difficult to maintain modern waste management in a sustainable way. Primarily, municipal solid waste treatment plants are at increased risk. The probability that treatment plants burn to the ground is far too high, according to the available assessment. The increased number of major fires in waste management in recent years is clear and undeniable evidence. 
No other substance or material has ever comparably endangered the whole waste industry. Hence, besides research and development activities for investigating and understanding the hazards and risks of lithium-based portable batteries, increased technological development and innovation efforts are indispensable for reducing the risk potential of end-of-life portable batteries.

In order to reduce risk, the waste sector has to aim to collect as many batteries as possible in the separate collection systems and take-back schemes, as only this collection system guarantees a damage-free return system. That requires increased effort in public relations and consumer awareness-raising. However, a 100\% separate collection rate for portable batteries is highly unrealistic without a comprehensive deposit system. Hence, operators of treatment facilities have to find ways to (1) protect critical infrastructure and treatment processes (e.g., including new detection and extinguishing methods) or (2) preferably detecting and separating portable batteries in the course of their treatment processes.

Further research is necessary in order to gain more specific knowledge on the influence factors, where assumptions had to be made in the present study. Especially, the probability of waste ignition due to the thermal runaway of portable batteries has to be investigated.

Supplementary Materials: The following are available online at https:/ / www.mdpi.com/2227-971 $7 / 9 / 1 / 49 /$ s1.

Author Contributions: Conceptualization, T.N. and R.P.; Data curation, T.N. and M.B.; Formal analysis, T.N. and M.B.; Funding acquisition, R.P.; Investigation, T.N. and M.B.; Methodology, T.N. and M.H.; Project administration, T.N.; Resources, T.N. and R.P.; Software, T.N.; Supervision, R.P.; Validation, T.N., M.H. and R.P.; Visualization, T.N.; Writing-original draft, T.N. and M.H.; Writingreview \& editing, T.N. All authors have read and agreed to the published version of the manuscript.

Funding: This research was funded by the Austrian Research Promotion Agency, grant number 850753 .

Data Availability Statement: The data presented in this study are available on request from the corresponding author. The data are not publicly available due to privacy restrictions.

Acknowledgments: The authors thank T. Bäck, L. Kranzinger, P. Puchbauer, W. Rübenbauer, S. Schlögl, B. Steiner, and the members of the Chairs working group 'Environmental Analytics' for their support in the sampling and sorting campaign. Furthermore, the authors thank the Austrian Research Promotion Agency for funding and the project partners for support.

Conflicts of Interest: The authors declare no conflict of interest. The funders had no role in the design of the study; in the collection, analyses, or interpretation of data; in the writing of the manuscript, or in the decision to publish the results.

\section{References}

1. Nigl, T.; Rübenbauer, W.; Pomberger, R. Cause-Oriented Investigation of the Fire Incidents in Austrian Waste Management Systems. Detritus 2020, 9, 213-220. [CrossRef]

2. LANUV (Landesamt für Natur, Umwelt und Verbraucherschutz Nordrhein-Westfalen). Brandereignisse in AbfallbehandlungsanlagenAbschlussbericht und Schlussfolgerungen der Landesregierung; LANUV-Fachbericht 68: Recklinghausen, Germany, 2016. (In German)

3. Ibrahim, M.A.; Alriksson, S.; Kaczala, F.; Hogland, W. Fires at storage sites of organic materials, waste fuels and recyclables. Waste Manag. Res. 2013, 31, 937-945. [CrossRef] [PubMed]

4. Nigl, T.; Pomberger, R. Brandrisiko durch Lithium-Ionen Batterien: Sind unsere Anlagen noch versicherbar? In Berliner RecyclingUnd Sekundärrohstoffkonferenz, Berlin, Germany, 2-3 March 2020; Holm, O., Thomé-Kozmiensky, E., Goldmann, D., Friedrich, B., Eds.; Thomé-Kozmiensky Verlag GmbH: Neuruppin, Germany, 2020; pp. 482-494. ISBN 978-3-944310-51-0. (In German)

5. Nigl, T.; Schwarz, T.E.; Walch, C.; Baldauf, M.; Rutrecht, B.; Pomberger, R. Characterisation and Material Flow Analysis of End-of-Life Portable Batteries and Lithium-based Batteries in Different Waste Streams in Austria. Waste Manag. Res. 2020, 38 , 649-659. [CrossRef] [PubMed]

6. EAK (Elektroaltgeräte Koordinierungsstelle). Tätigkeitsbericht 2015. Available online: https://www.eak-austria.at/presse/ (accessed on 1 November 2020). (In German).

7. EAK (Elektroaltgeräte Koordinierungsstelle). Tätigkeitsbericht 2017. Available online: https://www.eak-austria.at/presse/ (accessed on 1 November 2020). (In German).

8. Lisbona, D.; Snee, T. A review of hazards associated with primary lithium and lithium-ion batteries. Process. Saf. Environ. Prot. 2011, 89, 434-442. [CrossRef] 
9. Winslow, K.M.; Laux, S.J.; Townsend, T.G. A review on the growing concern and potential management strategies of waste lithium-ion batteries. Res. Conserv. Recycl. 2018, 129, 263-277. [CrossRef]

10. Mikolajczak, C.; Kahn, M.; White, K.; Long, R.T. Lithium-Ion Batteries Hazard and Use Assessment, 1st ed.; Springer: New York, NY, USA, 2011; pp. 43-70. [CrossRef]

11. Golubkov, A.W.; Scheikl, S.; Planteu, R.; Voitic, G.; Wiltsche, H.; Stangl, C.; Fauler, G.; Thaler, A.; Hacker, V. Thermal runaway of commercial 18650 Li-ion batteries with LFP and NCA cathodes-impact of state of charge and overcharge. RSC Adv. 2015, 5, 57171-57186. [CrossRef]

12. Liu, X.; Stoliarov, S.I.; Denlinger, M.; Masias, A.; Snyder, K. Comprehensive calorimetry of the thermally-induced failure of a lithium ion battery. J. Power Sources 2015, 280, 516-525. [CrossRef]

13. Nordsieck, H.; Förster, A.; Martin, A.; Zepf, V.; Hertel, M. Sicheres Sammeln von Elektroaltgeräten in Depotcontainersystemen; University of Augsburg and Bifa: Augsburg, Germany, 2016. (In German)

14. Nigl, T.; Bäck, T.; Stuhlpfarrer, S.; Pomberger, R. The Fire Risk of Portable Batteries in Their End-of-Life-Investigation of the State of Charge of Waste Lithium-Ion Batteries in Austria. Waste Manag. Res. 2020. submitted for publication. [CrossRef]

15. ISO. Safety of Machinery_General Principles for Design_Risk Assessment and Risk Reduction; EN ISO 12100:2010; ISO: Geneve, Switzerland, 2010.

16. Rausand, M. Risk Assessment: Theory, Methods, and Applications; John Wiley \& Sons: Hoboken, NJ, USA, 2013; pp. 1-28. ISBN 978-1-118-28110-9.

17. VdS. Kunststoffe-Eigenschaften, Brandverhalten, Brandgefahren. VdS 2000, 2516, 2000-2012. (In German)

18. Grammelis, P.; Basinas, P.; Malliopoulou, A.; Sakellaropoulos, G. Pyrolysis kinetics and combustion characteristics of waste recovered fuels. Fuel 2009, 88, 195-205. [CrossRef]

19. Graf, S.H. Ignition Temperatures of Various Papers, Woods and Fabrics. Engineering Experiment Station Oregon State System of Higher Education, Bulletin 26; Oregon State College: Corvallis, OR, USA, 1949.

20. Jhu, C.Y.; Wang, Y.W.; Shu, C.M.; Chang, J.C.; Wu, H.C. Thermal explosion hazards on 18650 lithium ion batteries with a VSP2 adiabatic calorimeter. J. Hazard. Mater. 2011, 192, 99-107. [CrossRef]

21. Sturk, D.; Hoffmann, L.; Tidbald, A.A. Fire Tests on E-vehicle Battery Cells and Packs. Traffic Inj. Prev. 2015, 16, 159-164. [CrossRef]

22. BMNT. Die Bestandsaufnahme der Abfallwirtschaft in Österreich—Statusbericht 2018; Bundesministerium für Nachhaltigkeit und Tourismus: Vienna, Austria, 2018. (In German)

23. BMK. Die Bestandsaufnahme der Abfallwirtschaft in Österreich-Statusbericht 2020 (Referenzjahr 2018); Bundesministerium für Klimaschutz, Umwelt, Energie, Mobilität, Innovation und Technologie: Vienna, Austria, 2020. (In German)

24. Franks, A.; Whitehead, R.; Crossthwaite, P.; Smail, L. Application of QRA in Operational Safety Issues; Research Report 25; HSE Books: Buxton, UK, 2002; ISBN 0-7176-2570-2.

25. Cox, L.A. What's Wrong with Risk Matrices? Risk Anal. 2008, 28, 497-512. [CrossRef] [PubMed]

26. Autischer, M.; Holzschuster, S.; Nigl, T. Statistische Betrachtung von Infrarot-Sensordaten in der Aufbereitung mit Relevanz zur Brandfrüherkennung. In Proceedings of the Recy \& DepoTech 2020, Leoben, Austria, 18-20 November 2020; pp. 287-294, ISBN 979-3-200-07190-2. (In German).

27. Nigl, T.; Bäck, T.; Pomberger, R. Vertiefende Ursachenforschung zu Brandereignissen in der österreichischen Abfall-, Entsorgungsund Recyclingwirtschaft. In Proceedings of the Recy \& DepoTech 2020, Leoben, Austria, 18-20 November 2020; pp. 279-286, ISBN 979-3-200-07190-2. (In German). 